\section{Олеся Столярчук,}

кандидат психологічних наук, дочент, доцент кафедри загальної, вікової та педагогічної психології Київського університету імені Бориса Грінченка.

\author{
Olesia Stoliarchuk, \\ Ph.D. in Psychology, Associate Professor of \\ Department of General, Age and \\ Pedagogical Psychology of Boris Grinchenko \\ Kiev University.
}

\section{Оксана Сергєєнкова,}

доктор психологічних наук, професор,

завідувач кафедри загальної, вікової та

педагогічної психології Київького

університету імені Бориса Грінченка.

E-mail: o.serhieienkova@kubg.edu.ua

ORCID 0000-0002-1380-7773

\section{Oxana Serhieienkova,}

Doctor of Psychology,

Heard of Department of General, Age and Pedagogical Psychology of Boris Grinchenko Kiev University.

\title{
ФОРМУВАННЯ ПСИХОЛОГІЧНОЇ ГОТОВНОСТІ СТУДЕНТІВ ДО МАЙБУТНЬОЇ ПРОФЕСІЙНОЇ ДІЯЛЬНОСТІ
}

У статті розкрито зміст, функиії та складові компоненти поняття психологічної готовності студента до фахової діяльності як індикатора успішності його професіоналізації. Запропоновано розширене тлумачення психологічної готовності особистості студента до фахової діяльності як загальної спрямованості на професійну діяльність у річищі життєвої самореалізаиіі. Проаналізовано результати реалізації програми гармонізації становлення особистості майбутнього фахівия за вектором формування психологічної готовності до професійної діяльності. Зафіксовано висхідну динаміку психологічної готовності до професійної діяльності у студентів експериментальних груп. Підтверджено ефективність рефлексивно-проектувальної технології як засобу формування психологічної готовності студентів до майбутньої фахової діяльності. Доведено, що високий рівень психологічної готовності випускника до професійної діяльності забезпечується не стихійним чи супутнім освітнім впливом, а формується внаслідок цілеспрямованого психологічного супроводу професіоналізачії студента.

Ключові слова: професіоналізація, психологічна готовність до професійної діяльності, студент, майбутній фахівецьь, професійне становлення, професійне навчання, становлення особистості фахівия, гармонізація професійного становлення.

The problem of the formation of students' psychological readiness to future professional activity was considered in the article. It was found, that professional studying is a leading stage for professional becoming of future specialist. A psychological readiness to future professional activity is an important indicator of a becoming of a specialist's personality. The content, functions and constituents of the concept of students ' psychological readiness for professional activity were considered in the article. The students' psychological readiness to professional activity is interpreted as their general orientation to professional activity in conditions of life self-realization.

The results of the implementation of the program of harmonization of future specialist' personality becoming were analyzed. This program was implemented at the Boris Grinchenko Kyiv University, 185 students of the first, third and fourth year were involved in the formation program. The program of harmonization of students, professional becoming combines individualization, professionalization and universalization as vectors of its realization. The ascending dynamics of psychological readiness for professional activity was fixed in students of experimental groups. The highest growth rates were found among the students of the third experimental group. These students were studied the course «Psychology of self-knowledge and professional self-realization». The effectiveness of reflexive and projective educational technology as a means of formation of students' psychological readiness to future professional activity was been confirmed also. It was proved, that the high level of psychological readiness of a graduate to professional activity is not formed spontaneously. A purposeful psychological support for the student' professionalization is forms his readiness to professional activity. So, effectiveness of external management of the dynamics of students' psychological readiness to future professional activity is proved.

Keywords: professionalization, psychological readiness to future professional activity, student, future specialist, professional becoming, professional studying, becoming of a specialist's personality, harmonization of professional becoming. 
Постановка проблеми. Методологічним підгрунтям реалізації професійної підготовки вітчизняними закладами вищої освіти $є$ компетентнісний підхід, який здебільшого традиційно втілюється у засвоєному випускником соціально визначеному наборі фахових знань, умінь і навичок, що забезпечують адаптацію особистості в межах певної спеціалізації. На цьому тлі формування ряду особистісних надбань майбутніх фахівців зберігає супутній характер. Результатом цього $є$ суперечності між високим рівнем професійної компетентності та низьким рівнем фахової мотивації випускників закладів вищої освіти. Також не втрачає актуальності, незважаючи на багаторічний досвід вивчення зарубіжними та вітчизняними психологами, проблема психологічної готовності майбутнього фахівця до професійної діяльності. Сформованість цієї готовності постає платформою для успішності адаптації початківця до умов професійної діяльності. Відповідно, моніторинг ступеня психологічної готовності студента до майбутньої фахової діяльності $є$ важливим прикладним завданням закладів вищої освіти.

Аналіз останніх досліджень і публікацій. Ряд дослідників наголошують на вагомій ролі фахового навчання у загальному професіогенезі особистості. Досить чітко й об'ємно сформулювали вектори розвитку особистості студента як майбутнього фахівця білоруські психологи М. Дьяченко та Л. Кандибович. Дослідники вважали, що під час фахового навчання у студента:

- міцніє професійна спрямованість, розвиваються необхідні здібності;

- вдосконалюються, «професіоналізуються» психічні процеси, стани, досвід;

- зростає почуття обов'язку, відповідальність, професійна самостійність, більш рельєфно постає індивідуальність студента, його життєва позиція;

- зростають домагання студента в межах своєї майбутньої спеціальності;

- на основі інтенсивної передачі соціального і професійного досвіду та формування необхідних якостей збагачується соціальна, духовна й моральна зрілість особистості майбутнього фахівця;

- активізується самовиховання студента у формуванні якостей, досвіду, необхідних йому як майбутньому суб'єкту професійної діяльності;

- зміцнюється професійна самостійність і готовність до майбутньої фахової діяльності [Дяченко, 1989: с. 47].

Аналізуючи феномен готовності випускника закладу вищої освіти до професійної діяльності, доречно відрізняти ії від поняття професійної придатності. Вищевказані психологи зробили акцент на психологічній платформі готовності як сформованому бажанні, прагненні працювати за фахом. Дослідники розкривали зміст психологічної готовності через інтегральні характеристики особистості майбутнього педагога, що включають в себе інтелектуальні, емоційні та вольові властивості, професійно-моральні переконання, потреби, звички, знання, вміння $\mathrm{i}$ навички, педагогічні здібності. У структуру психологічної готовності до педагогічної діяльності вищезазначені вчені включили такі компоненти, як мотиваційний, орієнтаційний, пізнавально-оперативний, емоційно-вольовий, психофізіологічний та оцінювальний [Дяченко, 1989: c. 101].

Готовність до професійної діяльності разом із фаховою ідентичністю Е. Зеєр вважас провідними новоутвореннями ідентифікації як завершального етапу професійної освіти. Для випускників важливо знайти професійне поле самореалізації, виробити особистісні смисли майбутньої фахової діяльності, зорієнтуватись на ринку праці. Психологічними критеріями успішності проходження етапу ідентифікації вчений вбачає ототожнення випускника 3 майбутньою 
професією, формування готовності до фахової діяльності та розвинуту здатність до професійної самопрезентації [Зеєр, 2006: с. 269-271].

Деталізуючи структуру професіоналізму, Ю. Поваренков визначає іiі компонентами операційний, що виявляється у наявності та задіяності кваліфікаційних знань, умінь, навичок, здібностей (професійна компетентність); мотиваційний, що зосереджує актуальні для особистості мотиви фахової діяльності (професійна спрямованість); смисловий, якому властиві сформована Я-концепція професіонала i професійна самооцінка (професійна самосвідомість). Всі ці компоненти активно формуються упродовж фахового навчання. Інтегральним критерієм успішної фахової підготовки вчений вважає готовність до професійної діяльності, що спирається на сформовану фахову мотивацію, компетентність і професійно значущі якості особистості [Поваренков, 2002: с. 87].

Дослідниця Є. Шипілова зазначає, що поняття готовності до професійної діяльності майбутніх психологів має складну структуру, яка включає в себе ряд компонентів: ціннісно-мотиваційний, когнітивно-гностичний, емоційно-вольовий, функціонально-діяльнісний i креативний, а також послідовно досягає в своєму розвитку таких рівнів, як орієнтувальний, операційний, функціональний i рефлексивно-творчий. Учена свідома того, що готовність до професійної діяльності $\epsilon$ явищем динамічним. Формуючись у процесі фахового навчання, психологічна готовність до професійної діяльності студентів-психологів зазнає позитивних якісних і кількісних змін, нарощується та виявляється у поступальній динаміці переходу від одного рівня до іншого, визначається внутрішнім балансом між іiі компонентами i забезпечує продуктивне вирішення навчальних i професійних завдань різної складності та змісту - від репродуктивних до евристичних [Шипілова, 2007].

Психологічна готовність виражається через активне позитивне ставлення до перспектив початку професійної діяльності, усвідомлення можливостей ії успішного здійснення шляхом мобілізації та реалізації особистісного потенціалу. Можна розглядати психологічну готовність до фахової діяльності одним із важливих чинників успішної адаптації початківця та підгрунтям професійної самореалізації. За твердженням Л. Субботіної, готовність не тільки показує можливість, схильність суб'єкта діяти на досить високому рівні, але і виступає вирішальною умовою швидкої адаптації до праці, подальшого професійного вдосконалення і підвищення кваліфікації [Субботіна, 2011: с. 296].

Таким чином, вищезазначені вчені схильні тлумачити поняття психологічної готовності до професійної діяльності лише в контексті стратегії формування монопрофесіоналізму студента. Однак ми розглядаємо психологічну готовність до професійної діяльності не лише на тлі того фаху, який здобуває студент у закладі вищої освіти, а як загальну спрямованість на професійну діяльність у річищі життєвої самореалізації. Загалом структура психологічної готовності особистості до професійної діяльності складається 3 когнітивної, емоційної та мотиваційної складових. Когнітивна складова містить комплекс уявлень і знань про діяльність, іiі зміст і наслідки. Емоційна складова втілюється у комплексі переживань і ставлень, в тому числі можливих страхах і побоюваннях 3 приводу успішності чи неуспішності діяльності. Системоутворюючим ядром психологічної готовності до професійної діяльності $€$ зміст мотиваційної сфери випускника, його готовність до самоактуалізації та саморозвитку, спрямованість на реалізацію власного творчого потенціалу особистості. Індикаторами стійкої психологічної готовності до 
професійної діяльності постають стійкі інтереси та настанови студента до обраного фаху, задоволеність своїм професійним вибором і впевненість в успіху, реалістичне уявлення свого професійного майбутнього та визнання значущості фахової діяльності для досягнення життєвої мети, почуття професійної та соціальної відповідальності. У такому ракурсі психологічна готовність до професійної діяльності як особистісне новоутворення випускника постає важливим локальним об'єктом цілеспрямованого формувального впливу під час фахової підготовки, що і стало предметом нашого дослідження.

Мета написання статmi - опис і аналіз результатів апробації програми гармонізації особистісно-професійного становлення студентів у векторі формування ïx психологічної готовності до майбутньої професійної діяльності.

Виклад основного матеріалу. Проведене нами емпіричне дослідження виявило розповсюдженість складнощів і суперечностей особистісного становлення майбутніх фахівців на етапі їх професійної підготовки. Цей факт зумовив доречність розроблення й апробації програми гармонізації становлення особистості майбутнього фахівця, яка була реалізована у річищі трьох змістових векторів індивідуалізації, професіоналізації й універсалізації. Одним із провідних індикаторів успішності реалізації програми постала психологічна готовність студентів до майбутньої професійної діяльності.

Експериментальною базою дослідження став Київський університет імені Бориса Грінченка, загальний обсяг вибірки охоплював 185 студентів першого, третього та четвертого курсів спеціальностей «Філологія (англійська)», «Психологія», «Практична психологія», «Право» та ін. Всі представники обраної для експерименту вибірки були поділені на три експериментальні та три контрольні групи. Перша експериментальна група, яка складались із 32 студентів першого курсу спеціальності «Філологія (англійська)», була залучена до реалізації рефлексивнопроектувальної технології навчання при викладанні курсу «Психологія». Результати впровадження цього напряму програми порівнювались із діагностичними даними першої контрольної групи, що охоплювала 32 першокурсників тієї ж спеціальності, які вивчали психологію у традиційному режимі ії викладання.

Другий напрям програми передбачав використання атласу професіоналізації 333 студентами четвертого курсу, які опановують педагогічний, психологічний i юридичний фах. Ці студенти склали вибірку другої експериментальної групи, діагностичні показники якої порівнювались із даними другої контрольної групи 3 аналогічною кількістю осіб і спеціальностей. Представники третьої експериментальної групи у складі 27 студентів третього курсу різних спеціальностей, були залучені до вивчення спецкурсу «Психологія самопізнання та професійної самореалізації». Їх діагностична картина порівнювалась із показниками третьої контрольної групи, що об'єднувала вибірку 28 третьокурсників, яким вищевказаний спецкурс не викладався.

Виокремлення та реалізація трьох напрямів реалізації програми гармонізації особистісного становлення майбутніх фахівців надали можливість порівняти динаміку показників формування психологічних надбань професійної підготовки не тільки у представників експериментальних і контрольних груп, а й у учасників окремих психолого-педагогічних заходів реалізації програми формувального впливу.

Первинний діагностичний зріз виявив початкові значення рівня психологічної готовності до професійної діяльності у студентів експериментальних і контрольних груп. Цілком логічним було те, що загальні показники цього рівня 
виявились на початку формувального експерименту в першої експериментальної та першої контрольної груп досить посередніми, що зумовлено їх статусом першокурсників і початком здобуття професії. Як і в першій експериментальній, так і в першій контрольній групах кількість носіїв високого рівня готовності до фахової діяльності становила лише 6\%, близько половини вибірки нараховували носії середнього рівня (41\% і 44\% відповідно), а найчисленнішою зафіксовано підгрупу першокурсників з низьким рівнем (53\% і 50\% відповідно). Детально результати дослідження цього критерію викладено у таблиці 1.

Таблиця 1

Діапазон змін готовності майбутніх фахівців до професійної діяльності

\begin{tabular}{|c|c|c|c|c|}
\hline \multirow{2}{*}{$\begin{array}{c}\text { Дослідницька } \\
\text { група }\end{array}$} & \multirow{2}{*}{$\begin{array}{c}\text { Рівні } \\
\text { готовності }\end{array}$} & \multicolumn{2}{|c|}{ Кількість носіїв (\%) } & \multirow{2}{*}{$\begin{array}{c}\text { Статистика } \\
\text { змін }\end{array}$} \\
\hline & & $\begin{array}{c}\text { початок } \\
\text { експерименту }\end{array}$ & $\begin{array}{c}\text { кінець } \\
\text { експерименту }\end{array}$ & \\
\hline \multirow{3}{*}{$\begin{array}{c}\text { Перша } \\
\text { експериментальна } \\
(\mathrm{n}=32)\end{array}$} & Високий & 6 & 9 & +3 \\
\hline & Середній & 41 & 59 & +18 \\
\hline & Низький & 53 & 32 & -21 \\
\hline \multirow{3}{*}{$\begin{array}{c}\text { Перша контрольна } \\
(\mathrm{n}=32)\end{array}$} & Високий & 6 & 3 & -3 \\
\hline & Середній & 44 & 47 & +3 \\
\hline & Низький & 50 & 50 & - \\
\hline \multirow{3}{*}{$\begin{array}{c}\text { Друга } \\
\text { експериментальна } \\
(\mathrm{n}=33)\end{array}$} & Високий & 24 & 61 & +37 \\
\hline & Середній & 64 & 36 & -28 \\
\hline & Низький & 12 & 3 & -9 \\
\hline \multirow{3}{*}{$\begin{array}{c}\text { Друга контрольна } \\
(\mathrm{n}=33)\end{array}$} & Високий & 24 & 36 & +12 \\
\hline & Середній & 67 & 61 & -6 \\
\hline & Низький & 9 & 3 & -6 \\
\hline \multirow{3}{*}{$\begin{array}{c}\text { Третя } \\
\text { експериментальна } \\
(\mathrm{n}=27)\end{array}$} & Високий & 22 & 78 & +56 \\
\hline & Середній & 59 & 22 & -37 \\
\hline & Низький & 19 & - & -19 \\
\hline \multirow{3}{*}{$\begin{array}{c}\text { Третя } \\
\text { контрольна } \\
(\mathrm{n}=28)\end{array}$} & Високий & 21 & 36 & +15 \\
\hline & Середній & 61 & 46 & -15 \\
\hline & Низький & 18 & 18 & - \\
\hline
\end{tabular}

Внаслідок застосування зі студентами першої експериментальної групи рефлексивно-проектувальної технології викладання психології у них було зафіксовано позитивну динаміку психологічної готовності до професійної діяльності. Так, кількість носіїв низького рівня зменшилась на 21\% 3 відповідним зростанням на 18\% вибірки носіїв середнього рівня та на $3 \%$ носіїв високого рівня. Не надто вагомі, на перший погляд, зрушення вважаємо абсолютно прийнятними для студентів першого року навчання, значні особистісні ресурси яких першочергово використані на адаптацію до умов навчання в закладі вищої освіти. Це підтверджується і результатами повторного діагностичного зрізу щодо студентів першої контрольної групи. Їх показники майже не змінились: на 3\% зменшилась кількість носіїв високого рівня психологічної готовності до професійної діяльності із відповідним поповненням вибірки студентів з середнім рівнем. 
Аналіз динаміки готовності студентів до професійної діяльності 3 використанням Т-критерію Вілкоксона засвідчив достовірність змін цього показника у першій експериментальній групі $\left(\mathrm{T}=3,606^{* *}\right.$ при $\left.\mathrm{p}=0,000\right)$. У першій контрольній групі статистично значущих змін не виявлено, що підтвердило позитивну динаміку психологічної готовності до фахової діяльності у студентів першої експериментальної групи саме за рахунок застосування рефлексивно-проектувальної технології вивчення психології.

У другій експериментальній i контрольній групах, учасники яких завершували бакалаврське навчання, показники психологічної готовності на початку формувального експерименту були вищими, ніж у перших групах. Так, кількість носіїв низького рівня становила у другій експериментальній та другій контрольній групах 24\% (табл. 1). Вибірка носіїв середнього рівня, що була найбільшою в обох групах, сягала 64\% і 67\% відповідно. Оптимальний для випускників високий рівень психологічної готовності до фахової діяльності виявлено лише у 12\% студентів другої експериментальної групи та 9\% другої контрольної групи. Внаслідок системного психологічного супроводу учасників третьої експериментальної групи із застосуванням атласу професіоналізації показники їх готовності до фахової діяльності значно покращились. Зокрема, зросла на 37 \% кількість носіїв високого рівня, досягнувши 61\% за рахунок зменшення вибірки на $9 \%$ носіїв низького рівня та на $28 \%$ носіїв середнього рівня.

Позитивна динаміка показників психологічної готовності до фахової діяльності зафіксована й у студентів другої контрольної групи. Виявлено зростання на $12 \%$ кількості носіїв високого рівня при супутньому зменшенні на $6 \%$ вибірок носіїв низького і середнього рівня. Проте обсяг позитивних зрушень за означеним показником, зафіксований у другій контрольній групі, втричі менший, ніж у другій експериментальній. Це дає підстави для пояснення детермінації суттєвої позитивної динаміки психологічної готовності до фахової діяльності, зафіксованої у другій експериментальній групі, саме ефективним формувальним впливом. Застосування Ткритерію Вілкоксона підтвердило цю тезу, оскільки виявлено високу достовірність змін у другій експериментальній групі $(\mathrm{T}=3,873 * *$ при $\mathrm{p}=0,000)$ та помірну - у другій контрольній групі (T=2,449* при $\mathrm{p}=0,014)$.

Найбільш значні позитивні зміни внаслідок реалізації третього вектору формувального експерименту виявлено в учасників третьої експериментальної групи, які опанували зміст спецкурсу «Психологія самопізнання та професійної самореалізації». Перший діагностичний зріз зафіксував, що лише близько п'ятої частини третьокурсників мають високий рівень готовності до фахової діяльності (22\% у третій експериментальній групі та $21 \%$ у третій контрольній групі) (табл. 1). Частина студентів засвідчила низький рівень на початку експерименту (19\% та 18\% відповідно), а більшість були носіями середнього рівня - 59\% студентів третьої експериментальної групи та $61 \%$ студентів третьої контрольної групи.

Повторний діагностичний зріз по завершенню формувального експерименту виявив сприятливу динаміку психологічної готовності до фахової діяльності у студентів обох груп, однак обсяги позитивних зрушень є різними. У студентів третьої експериментальної групи анулювалась вибірка носіїв низького рівня, зменшилась на $37 \%$ кількість носіїв середнього рівня, досягнувши позначки $22 \%$. Водночас на 56\% поповнилась підгрупа учасників, що засвідчили високий рівень психологічної готовності до фахової діяльності, нараховуючи загалом 78\%. У третій контрольній групі кількість носіїв низького рівня не змінилась. Виявлено зменшення 
на 15\% вибірки носіїв середнього рівня 3 відповідним поповненням кількості студентів 3 високим рівнем готовності. Повторний зріз зафіксував обсяг їх вибірки на позначці 36\%. Показники критерію Вілкоксона підтвердили наявність змін в обох групах, однак позитивна динаміка психологічної готовності до фахової діяльності у представників третьої експериментальної групи є більш вагомою та достовірною $(\mathrm{T}=4,472 * *$ при $\mathrm{p}=0,000)$, ніж у студентів третьої контрольної групи $\left(\mathrm{T}=2,005^{*}\right.$ при $\mathrm{p}=0,046)$.

Загалом зазначимо, що професійне навчання сприяє розвитку психологічної готовності студентів до фахової діяльності, однак більш-менш виразні позитивні зміни зафіксовано лише у старшокурсників. Водночас, обсяг цих змін далекий від бажаного, оскільки лише близько третині студентів контрольних груп притаманний високий рівень означеної характеристики. Така статистика свідчить про супутній характер формування психологічної готовності особистості до фахової діяльності та вказує на необхідність впровадження цілеспрямованих заходів формувального впливу. Ефективним виразником цього впливу постала рефлексивно-проектувальна освітня технологія із застосуванням атласу професіоналізації, що доведено в процесі формувального експерименту.

Висновки. Отже, професійне навчання $є$ значущим етапом професійного становлення особистості. Вагомим індикатором успішності професіоналізації студента є рівень його психологічної готовності до майбутньої фахової діяльності. Це поняття доречно розглядати не лише у ракурсі здобуття певної професії, але як загальну спрямованість особистості на самореалізацію у фаховій діяльності. Психологічна готовність до професійної діяльності не формується стихійно чи автоматично внаслідок фахової підготовки студента, а потребує цілеспрямованого психологічного супроводу професіоналізації майбутніх фахівців. Одним із провідних напрямів реалізації програми гармонізації становлення особистості майбутніх фахівців є підвищення рівня їх психологічної готовності до професійної діяльності, висхідну динаміку якої зафіксовано під час формувального експерименту.

Перспективи подальших наукових розвідок вбачаємо у встановленні характеру зв'язку між психологічною готовністю студентів до фахової діяльності та рівнем сформованості їх професійного універсуму.

\section{ЛIТЕРАТУРА}

Дьяченко, 1981 - Дьяченко М. И. Психология высшей школы : ученик / М. И. Дьяченко, Л. А. Кандыбович. Минск : Издательство БГУ им. В. И. Ленина, 1981. - 383 с.

Зеер, 2006 - Зеер Э. Ф. Психология профессий : учеб. пособ. для студентов вузов / Э. Ф. Зеер. - М. : Академический Проект ; Фонд «Мир», 2006. - 336 с.

Поваренков, 2002 - Поваренков Ю. П. Психологическое содержание профессионального становления человека / Ю. П. Поваренков. - М. : Изд-во УРАО, 2002. - 160 с.

Субботина, 2011 - Субботина Л. Ю. Формирование профессиональной готовности студентов к самостоятельной деятельности. / Л. Ю. Субботина // Ярославский педагогический вестник. - 2011. № 4. - T. II. - C. 295-298.

Шипилова, 2007 - Шипилова Е. В. Формирование психологической готовности студентов-психологов к профессиональной деятельности : автореф. дис. на соиск. науч. степени канд. психол. наук : спец. 19.00 .07 «Педагогическая психология». - Москва, 2007. - 20 с.

\section{REFERENCES}

Dyachenko, 1981 - Dyachenko M. I. Psihologiya vyisshey shkolyi : uchenik / M. I. Dyachenko, L. A. Kandyibovich. - Minsk : Izdatelstvo BGU im. V. I. Lenina, 1981. - 383 s.

Zeer, 2006 - Zeer E. F. Psihologiya professiy : ucheb. posob. dlya studentov vuzov / E. F. Zeer. - M. : Akademicheskiy Proekt; Fond «Mir», 2006. - 336 s. 
Povarenkov, 2002 - Povarenkov YU. P. Psihologicheskoe soderzhanie professionalnogo stanovleniya cheloveka / YU. P. Povarenkov. - M. : Izd-vo URAO, 2002. - $160 \mathrm{~s}$.

Subbotina, 2011 - Subbotina L. YU. Formirovanie professionalnoy gotovnosti studentov k samostoyatelnoy deyatelnosti. / L. YU. Subbotina // YAroslavskiy pedagogicheskiy vestnik. - 2011. - № 4. - T. II. - S. 295298.

Shipilova, 2007 - Shipilova E. V. Formirovanie psihologicheskoy gotovnosti studentov-psihologov k professionalnoy deyatelnosti : avtoref. dis. na soisk. nauch. stepeni kand. psihol. nauk : spets. 19.00.07 «Pedagogicheskaya psihologiya». - Moskva, 2007. - 20 s.

УДК 316.334.22:130.123(092)

Ольга Стрілець, кандидат педагогічних наук, доцент кафедри мистецьких дисциплін і методик навчання ДВНЗ «Переяслав-Хмельницький державний педагогічний університет імені Григорія Сковороди».

\section{DOI 10.31470/2308-5126-2019-45-2-130-135}

\author{
Olga Strilets,
}

Ph.D. in Pedagogy, Associate Professor of the Department of Art Disciplines and Teaching Methods of the SHEI «PereiaslavKhmelnytskyi Hryhorii Skovoroda State Pedagogical University».

E-mail: ostrilets5@gmail.com

ORCID 0000-0003-1797-3784

\section{ПОГЛЯДИ ВАСИЛЯ СУХОМЛИНСЬКОГО НА ПРАЦЮ ЯК ДУХОВНУ ПОТРЕБУ ПІДРОСТАЮЧОГО ПОКОЛІННЯ}

У статті розглянуто питання актуальності формування у підростаючого покоління духовних цінностей. Розкрито важливість педагогічних порад великого педагога Василя Сухомлинського щуодо праці, як засобу виховання: «високоморальної, гуманістично спрямованої, фізично досконалої, естетично розвиненої особистості відданої своєму народові, своїй Батьківщині, яка не є байдужою до горя й біди інших людей, яка співчуває іншому та в разі потреби надає йому допомогу». Здійснений ретроспективний аналіз праць Василя Сухомлинського дозволив зробити висновок, щуо педагог надавав великого значення саме духовному вихованню дітей і стверджував про те: «що ідеал - ие духовна сериевина особистості. Прагнення до ідеалу - ие перший поштовх, стимул до самовиховання, без якого духовне життя особистості не $\epsilon$ повноцінним». 3 огляду на цее, вченому-педагогові важливим бачиться розвинути у підлітків, юнаків $і$ дівчат здатність бути вихованими, навчити їх виховувати самих себе. Обтрунтовано, щяо ідеї В. О. Сухомлинського щуодо духовного виховання підростаючого покоління засобами праці були, є $і$ будуть актуальними завжди.

Ключові слова: духовні цінності, високоморальність, ідеал, самовиховання, прачя, творча особистість, емоційно-естетичне виховання, творча прачяя.

The article deals with the relevance of the formation of spiritual values in the younger generation. The importance of the pedagogical councils of the great teacher Vasily Sukhomlinsky about labor as a means of education is revealed: if necessary, assists him. A retrospective analysis of the work of Vasily Sukhomlinsky led to the conclusion that the teacher attached great importance to the spiritual education of children and argued that «the ideal is the spiritual core of the personality. The pursuit of the ideal is the first impetus, the incentive to selfeducation, without which the spiritual life of the individual is not complete». As the term, the word «spirituality» is used in such sciences as philosophy, ethics on the definition of different concepts in one way or another tangible to the inner world of man. Spirituality is an ideal, to which the person sought and aspires to his own development, orientation to higher, absolute values, as well as the manifestation of the maturity of the psyche of the personality of the activity of the signaling system. The pedagogical problems of V.O. Sukhomlinsky are related to the problem of the formation of the spiritual nature of one of the third places. About the goal of the book of books and statuses, and the very same: "The Holy Spirit of the People of Our Hour», "The Spiritual Life of the Collective Collective», "The Spiritual Culture», «Creativity Is the Impetus of Spiritual Life» vihiovannya.

V. O. Sukhomlynsky convinced in his article «Work in the spiritual life of a teenager» What does an idea mean: labor is the basis of all-round development? In practical work with children and adolescents, this means that from the work there are strong strands of intellectual, moral, aesthetic, emotional, physical development until the formation of the ideological, civil basis of the individual. Education and labor can not be simplified, as practical consolidation, verification of the practice of knowledge acquired in the class. This problem is deep and sophisticated: mental development - labor, reason - labor. 